\title{
ジャガイモの菱腐れを起すPythium 菌
}

\author{
喜多 孝一・工藤 和一- (几州農業試験場)
}

\begin{abstract}
Occurrence of a stem-rot of potato caused by Pythium sp. Kouichi KITA and Kazuichi Kudo (Kyushu National Agricultural Experiment Station, Miyakonojo, Miyazaki 885)
\end{abstract}

1983年9月中旬に九州農試畑作部試験ほ場において， ジャガイモにPythium菌によるものと考えられる病害が ほ場全面に钼察された。我国においてPythium菌による ジャガイモの病害についての報告が見られないため，本 病害の病原菌の分離試験を行ったので結果を報告する。

病徵 ジャガイモの茎が地際部より喑緑色水浸状とな り倒伏する。また，地表に接した葉が黑色水浸状となり， 症状が進をと葉柄から茥に達し, 蕫が暗緑色水浸状とな り倒伏する。病組織内には無隔膜菌系および瞅胞子が多 数観察された。

菌の分離 分離には，医場上り採集した発病株を流水 でよく洗浄し，病斑部を切取って $\mathrm{HgCl}_{2} \quad 1,000$ 倍水溶液 で 1 分關消毒後, 殺菌水で 5 回洗浄し, 約 $5 \mathrm{~mm}$ の大きさ に切断して分離培地上に置いた。分離培地はストレプト マイシン40ppm, ピマリシン $60 \mathrm{ppm}$ ベンレート20ppm 加用 Difco $\mathrm{CMA}^{2)}$ 用い，分離温度は20〜22Cとした。 結果はPythium 菌のみが9 菌株分離され，いずれも同一 の形状を示した。

病原性の検定 分離されたPythium菌をジャガイモに 接種し発病を調查した。娭定にはバーミキュライトに载 培中のジャガイモ（品種デジマ）を用い，荎に無㰾接種 して，30C 湿室内に 2 日間保ち，発病を調查した。接種 原としては，ジャガイモ煎汁ショ糖寒天培地（PS A) で30C 1 日培養した菌そうの先端を切取って用いた。結

第 1 表 培盖温度と菌系発肯

\begin{tabular}{cc}
\hline \hline 温度 $(\mathrm{C})$ & 菌そう直径 $(\mathrm{mm})$ \\
\hline 5 & 0 \\
10 & 0 \\
15 & 11.0 \\
20 & 30.0 \\
25 & 46.0 \\
30 & 72.5 \\
35 & 74.7 \\
37 & 74.3 \\
40 & 62.7 \\
45 & 0 \\
\hline
\end{tabular}

PSA，19時間培盖，ペトリ IIL 5 枚平均值。
果は，ほ場で観察された病徴が再現された。そして，病 斑部から接種した菌と同様の菌が再分離されたことから 本菌を病原菌と判定した。

菌の発筒適温 P S A 平板培地で 30 C 1 日培養した菌

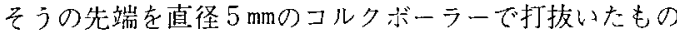

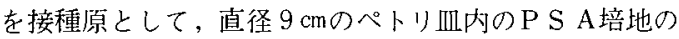
中央に接種し，異なる培煌温度での菌系発育を比較した。 培養温度は第 1 表の10段階とした。調查は培養19時間後 に行い，菌そうの直径を測定した。調查の結果，本菌の 菌系発育は15〜40Cの間で認められ，30４0Cの間で極 めて良好な発育を示し，最適温度は35C 付近にあるよう である。

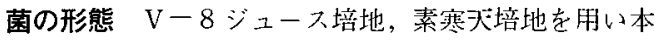
菌の形態観繁を行った。30Cの培絟温度で 1 日毎に顕微 鏡観察を行った結果，菌糸は透明で無隔膜，幅2.5〜5.1 $\mu \mathrm{m}$ で3.4 4.0 $\mu \mathrm{m}$ が最も多く平均 $3.6 \mu \mathrm{m}$ である。胞子の うは膨状で分岐し，遊走子に上る発芽が容易である。蔵 卵器は通常頂生で球形，表面はな山らかで膜はうすく，

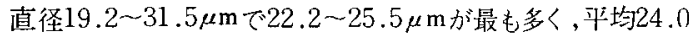
$\mu \mathrm{m}$ である。造精器は通常間生でタル形または半球形で 1 個着生し，同菌系または異菌糸性である。即胞子は厚膜 球形で非充満型、17.7 26.0 $\mu \mathrm{m}$ で20.0 21.3 $\mu \mathrm{m}$ が最 も多く，平均20.6 2 mである。
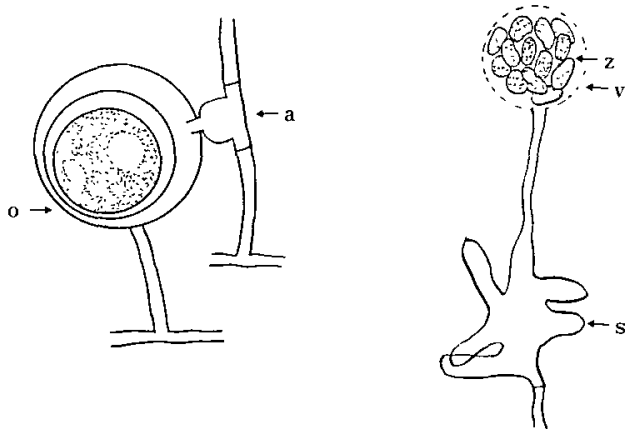

第 1 図分離菌の各種器管の形態

$\mathrm{a}$ : 造精器, o：卵胞子, $\mathrm{s}$ ：胞子のう, $\mathrm{v}$ : 球のう、 $\mathrm{z}$ : 遊走子 
第2 表 分離菌と Pythium aphanidermatumの各種器管の形態の比較

\begin{tabular}{|c|c|c|}
\hline 種 類 & 菌 ${ }^{\mathbf{a}}$ & P. aphanidermatum $\mathrm{b}$ \\
\hline 菌 & $\begin{array}{l}\text { 透明で無隔膜。 } \\
\text { 幅2.5〜 } 5.1 \mu \mathrm{m} \text { で3.4 4.0 } 4 \mu \mathrm{m} \text { が最も多く平均 } 3.6 \mu \mathrm{m} \text { 。 }\end{array}$ & $\begin{array}{l}\text { 同 左 } \\
2.8 \sim 7.3 \mu \mathrm{m} \text { で } 4 \text { - } 6 \mu \mathrm{m} \text { が萝い。 }\end{array}$ \\
\hline 胞子のう & 膨状で分岐する。遊走子が形成される。 & 同 \\
\hline 蔵 卯器 & $\begin{array}{l}\text { 通常頂生で球形，表面はなめらかで膜はうすい。 } \\
19.2 \sim 31.5 \mu \mathrm{m} \text { で22.2 25.5 } \mu \mathrm{m} \text { が最も多く平均 } 24 \mu \mathrm{m} 。\end{array}$ & $\begin{array}{l}\text { 同 左 } \\
22 \sim 27 \mu \mathrm{m}\end{array}$ \\
\hline 造 精 器 & $\begin{array}{l}\text { 通常間生で無柄，半球または夕ル形，1個着生する。 } \\
\text { 同菌系または異菌系性。 }\end{array}$ & 同 \\
\hline 卵胞子 & $\begin{array}{l}\text { 厚膜で球形, 非充満形。 } \\
17.7 \text { 26.0 } \mu \mathrm{m} \text { で20.0 21.3 } \mu \mathrm{m} \text { が最も多く平均 } 20.6 \mu \mathrm{m} \text { 。 }\end{array}$ & $\begin{array}{l}\text { 同 } \frac{1}{1} \\
17 \sim 19 \mu \mathrm{m}\end{array}$ \\
\hline
\end{tabular}

a 素寒天培地で30Cで培養。b MIDDLETON, J. T.の記載。

分離菌の分類 以上の結果から, 本菌の蔵卵器, 造精 器等各種器管の大きさ, 形態, 胞子のうの発芽方法, 菌系 発育適温等は MIDDLETON, MATTEWS, 等 3 ,4,7,8,91 の Pythium aphanidermatum の記載とよく一致するので，本菌はP. aphanidermatum-であると考えられるが，同定について は比較培嗂による娭討を要する。Pythium菌によるジヤ ガイモの病害はP. bultei, P. debarvanum, P. ultimum 等によるwaterry rot, waterry wound rot の報告 ${ }^{1,5}$ がある。また，P． aphanidermatum もジャガイモに対 し強い笴生性を有することが報告されているい，しかし， 我国においてP． aphanidermatum によるジャガイモの 地上部の病害については報告を見ないようであるが，本 病の発生は本年のように9月の気温が高く，特に本病発 生期の 9 月 1 〜 半旬の最高気温の平均はそれぞれ 30.4 C , $30.1 \mathrm{C} .29 .5 \mathrm{C}$ と極めて高く，また，降水量もそれ
ぞれ積算で $67.5 \mathrm{~mm}, 32.5 \mathrm{~mm}, 16.0 \mathrm{~mm}$ と多かったことが本 病発生の誘因となったものと考えられる。発生生態につ いては今後検討を要する。

\section{引用文 献}

1) Badilla, H. S. (1977) Review of Plant Pathology 50 ：85. 2）一谷多喜郎・新須利則（1981）日植病報 47 : 151-157. 3) Matrews, V.D. (1931) Studies on the genus Pythium. Univ. of N.C. Press, Chapel Hill : 1-136. 4 ) Middleton, J. T. (1943) Mem. Torr. Bott. Club $20: 55$ -61. 5) PETt, B. and $\mathrm{H}_{\text {AHN }}$, E. (1975) Review of Plant Pathology $54: 201.6$ 6) ReEN, L. (1972) Review of Plant Pathology 51:481-482. 7) 渡辺恒雄 （1980）農業および園芸 $55 ： 105-108$ 。 8）渡辺恒雄 （1981）農業および園芸 $56: 77-80.99$ ) 渡辺恒雄 (1981) 農業および園荎 $56: 103-108$ 。

(1984年 4 月27日 受領) 